\title{
EDITORIAL
}

\section{ESCRAVIDÃO E LIBERDADE NAS AMÉRICAS}

\author{
Slavery and freedom in the Americas \\ Esclavitud y libertad en las Américas
}

\author{
BERNARDo Borges BUARQUE DE HOLLANDA ${ }^{i *}$, \\ HTTPS://ORCID.ORG/0000-0001-7781-4684 \\ JOÃO MARCELO EHLERT MAIA ${ }^{\mathrm{I}^{*}}$
YNAÊ LOPES DOS SANTOS ${ }^{\mathrm{I}^{*}}$
}

EDITORES

o dia 02 de junho de 1888, duas semanas depois de abolida a escravidão, Angelo
Agostini e Luiz de Andrade afirmavam que "Na vida do Brasil, nenhum fato se poderá comparar ao do dia 13 de maio do corrente ano. A própria independência, ao lado da escravidão, era como uma data velada, uma conquista clandestina. Hoje sim, o Brasil é livre e independente". 0 entusiasmo dos editores da Revista Illustrada tinha uma razão faustosa: o Brasil finalmente abandonava a pecha de único país das Américas a manter a nefanda instituição, entrando assim para o rol das nações verdadeiramente livres e independentes.

Durante os anos subsequentes, o 13 de Maio foi comemorado como data máxima da liberdade nacional. Mas, assim como a independência parecia ser uma data velada, num país que mantinha a escravidão, a forma como a Primeira República festejou o Treze de Maio camu-

http://dx.doi.org/10.1590/S2178-14942018000300001

\footnotetext{
"Escola de Clências Sociais da Fundação Getulio Vargas (CPDOC/FGV) - Rio de Janeiro - Brasil.

*Professores da Escola de Ciências Sociais da Fundação Getulio Vargas (CPDOC/FGV) e Editores da Revista Estudos Históricos (bernardo.hollanda@fgv.br; joao.maia@fgv.br; ynae.santos@fgv.br)
} 
flou um sem-número de personagens e tramas que estiveram diretamente relacionados com a assinatura da Lei Áurea, bem como silenciou grande parte das violências e exclusões que marcaram os corpos e vidas de homens e mulheres cingidos pela escravidão. Tal silenciamento há muito era pauta de denúncias como a que foi feita em março de 1933 pelos dirigentes do jornal A Voz da Raça, um periódico "que se destinava à publicação de assuntos referentes aos negros", posto que "as outras folhas, aliás veteranas, por despeitos políticos, tem deixado de o fazer". Para os editores e jornalistas negros desse periódico, as comemorações da Abolição pareciam ter sentidos diversos daqueles apregoados por muitos abolicionistas que viam na liberdade o fim da escravidão, mas não enxergavam as dimensões do legado do escravismo.

A rememoração crítica dos 130 Anos da Abolição da Escravidão no dia 13 de maio de 2018 serviu como inspiração para o número 66 da Revista Estudos Históricos. No número que se propõe analisar Escravidão e Liberdade nas Américas, entramos em contato com pesquisas que consolidam e renovam a tradição historiográfica brasileira dos estudos sobre escravidão e Pós-Abolição, com destaque para as abordagens transnacionais ou "conectadas" que permitam reposicionar a agenda de investigações à luz de outras experiências no continente americano.

O número começa com o artigo de Ana Carolina Viotti, que, por meio de variado corpus documental, analisou a obrigatoriedade que recaía sobre os senhores no tocante à alimentação dos escravos no período colonial. A reconstituição de redes de compadrio em Minas Gerais na virada do século XVIII para a centúria seguinte é tema do artigo de Mateus Andrade, que por meio de estudos de demografia histórica demonstra a intrínseca relação entre a confirmação cotidiana da liberdade de indivíduos alforriados e o caráter sistêmico da escravidão na formação do Brasil. Outros significados de liberdade em meio ao mundo escravista e fronteiriço da região do Prata foram trabalhados por Hevelly Acruche, no contexto marcado pelas lutas de independência nos primeiros anos do século XIX. Partindo da política do Estado brasileiro, que, em consonância com os interesses da elite cafeicultura, retomou o tráfico transatlântico na ilegalidade após 1831, Walter Luiz Pereira e Thiago Campos Pessoa examinaram sujeitos e lugares do tráfico transatlântico no Sudeste do Brasil, que durante muito tempo foram silenciados pela historiografia. Por meio do exame de uma Ação de Liberdade movida por uma negra livre, vítima da prática ilícita de reduzir pessoas à escravidão, Virgínia Barreto demonstrou como a força da escravidão se fazia sentir, mesmo na vida de homens e mulheres negros que haviam nascido sob o signo da liberdade.

No sexto artigo, Alex Andrade Costa evidenciou, uma vez mais, como a escolha pela escravidão e a reabertura do tráfico transatlântico na ilegalidade (após 1831) envolveu uma série de autoridades públicas brasileiras. Numa proposta macroanalítica que parte da categoria de eco- 
nomia-mundo, Rafael Marquese apresenta como a escolha pela escravidão pode ser observada por meio de um novo regime visual da escravidão negra nas Américas, tomando os casos do Brasil cafeeiro e da Cuba açucareira como objetos de análise. No oitavo artigo, André Boucinhas utiliza corpus documental variado para examinar quais eram as condições de vida dos trabalhadores livres e escravizados da Corte imperial do Brasil na década de 1870. A criação em 1872 do Club Igualdad é o fio condutor por meio do qual Fernanda Oliveira avaliou a intrínseca relação entre a libertação de escravizados e a formação do Estado Republicano do Uruguai. No décimo artigo do dossiê, Juliano Sobrinho problematizou a participação do clero católico e presbiteriano na luta abolicionista nos últimos anos de vigência da escravidão brasileira.

As interfaces do abolicionismo transbordam as fronteiras nacionais no décimo primeiro artigo, no qual Luciana Brito examina a experiência de André Rebouças nos Estados Unidos marcado pelas políticas de segregação racial conhecidas como Jim Crow. No artigo seguinte, a trajetória de um consagrado (porém nem sempre lembrado) homem negro brasileiro - abolicionista, republicano e socialista - é o fio condutor que permite a Ana Flávia Magalhães Pinto revisitar as políticas de memória das pessoas livres do Brasil que viveram os últimos anos da escravidão e os primeiros tempos do Pós-Abolição. Por meio do exame interseccional do universo dos serviços domésticos, os sentidos de liberdade voltam a ser questionados no artigo de Natália Peçanha, que esmiúça os processos de criminalização das servidoras domésticas do Rio de Janeiro entre finais do século XIX e início do século XX. Tão importante quanto pensar e analisar sentidos e significados da escravidão e liberdade é examinar a produção da historiografia sobre tais questões. É exatamente esse o objetivo do décimo quarto artigo do dossiê, no qual Fabiane Popinigis e Paulo Terra examinam como a historiografia da História do Trabalho mais especificamente o GT Mundos do Trabalho, associado à Associação Nacional de História (Anpuh) - tem dialogado com os estudos sobre escravidão e Pós-Abolição. Por fim, o último artigo da revista, escrito por Moiséis Pereira Silva, permite pensar na longa duração do legado escravista no Brasil, na medida em que se utiliza das denúncias de trabalho escravo na região no Amazonas em plena década de 1970 para conceituar o trabalho escravo contemporâneo.

As abordagens teórico-metodológicas, os usos de fontes e os jogos de escalas presentes nos quinze artigos que compõem este número da Revista Estudos Históricos demonstram que, nas Américas, a multifacetada experiência de escravidão foi aspecto estruturante do continente, ao mesmo tempo em que as lutas pela liberdade revelam os avessos desses mesmos lugares. Fica o convite para a leitura. 


\section{REFERÊNCIAS}

Biblioteca Nacional. Hemeroteca Digital. Revista Illustrada, ano 13, n. 499, p. 2, 1888.

Biblioteca Nacional. Hemeroteca Digital. A Voz da Raça, ano 1, n. 1, p. 1, 1933. 